\title{
Exploring the seasonal dynamics within the benthic foraminiferal biocoenosis in a tropical monsoon-influenced coastal lagoon
}

\author{
Areen Sen, Punyasloke Bhadury* \\ Integrative Taxonomy and Microbial Ecology Research Group, Department of Biological Sciences, \\ Indian Institute of Science Education and Research Kolkata, Mohanpur 741246, Nadia, West Bengal, India
}

\begin{abstract}
Benthic foraminiferal assemblages are widely used as bioproxies for coastal environment monitoring. The present study investigated seasonal variations in live benthic foraminiferal assemblages over a period of 12 mo from the largest coastal lagoon in Asia, which is strongly influenced by tropical monsoons. The investigation revealed an extremely low diversity of benthic foraminiferal assemblages, comprising 12 species, of which 8 were agglutinated. The most dominant taxa throughout the study period belonged to the genus Ammonia. The living assemblage was restricted to the topmost $4 \mathrm{~cm}$ of the sediment, with the majority of assemblages occurring in the top $2 \mathrm{~cm}$. Data analysis revealed the presence of a significant variation in the biotic assemblage, indicating a patchy distribution. Overall, some of the benthic foraminiferal species, such as Ammomarginulina sp. and Miliammina obliqua, showed strong seasonal variation, while the dominant Ammonia spp. did not show any temporal variation. The environmental parameters displayed significant correlations with certain species, although no single factor could be identified as being the major force driving assemblage composition. The present findings of seasonality and correlations observed between certain factors with certain species may be utilized to improve biomonitoring in similar settings on a global scale.
\end{abstract}

KEY WORDS: Benthic foraminifera - Coastal lagoon ' Live assemblage - ANOSIM · UPGMA-based cluster · Ammonia

\section{INTRODUCTION}

Marginal marine environments along continental coastlines show wide habitat variability. Ranging from glacially formed fjords to coastal lagoons, marginal marine environments act as transitional ecotones between terrestrial and marine systems, and thus harbor unique biotic assemblages. Recent rises in sea level coupled with an unprecedented increase in global temperatures pose major threats to planktonic and benthic biotic assemblages characterizing marginal marine environments, including lagoons (Kennish 2002, Gilman et al. 2008, Anthony et al. 2009, Defeo et al. 2009). Benthic foraminifera are widely used as bioproxies for coastal environmental

\footnotetext{
${ }^{*}$ Corresponding author: pbhadury@iiserkol.ac.in
}

monitoring across a wide variety of marginal environments such as estuaries (Alve 1995, Luan \& Debenay 2005, Bhattacharjee et al. 2013), marshes (Gehrels \& Newman 2004, Horton \& Murray 2007) and lagoons (Samir 2000, Martins et al. 2013). However, the accuracy of such proxies is susceptible to seasonal variations in the assemblage structure. Previous long-term studies investigating seasonal variations in benthic foraminiferal assemblages from coastal environments have focused on the Indian River Lagoon (IRL), USA (Buzas \& Hayek 2000, Buzas et al. 2002) and the Hamble Estuary, UK (Murray \& Alve 2000), among others. Cyclical changes in foraminiferal species diversity were observed in the macrotidal Hamble Estuary (Murray \& Alve 2000),

() The author 2016. Open Access under Creative Commons by Attribution Licence. Use, distribution and reproduction are unrestricted. Authors and original publication must be credited. 
and Buzas and Hayek's (2000) observation from a single site in the IRL revealed summer densities of most species to be significantly greater than in other seasons spanning a period of $20 \mathrm{yr}$. A more detailed view generated from 4 study sites at the IRL over a period of $5 \mathrm{yr}$ (Buzas et al. 2002) revealed the absence of any conserved seasonal patterns.

Complexities in identifying seasonal changes in benthic foraminiferal assemblages inhabiting coastal marginal habitats arise from diurnal variations in tidal regime (Murray 2006). The effect of tide in shaping benthic foraminiferal communities is more pronounced in the intertidal zone (Horton et al. 2003, 2005, Horton \& Murray, 2007). Subtidal assemblages are shaped by salinity and the supply of detrital food matter (Murray 2006, Papaspyrou et al. 2013), factors that are influenced by tidal shifting in the water table alongside seasonal changes. Coastal lagoons with limited connection to an open marine source may be considered as marginal environments, where foraminiferal assemblage dynamics can be observed with the near-absence of tidal variations over a substantial period of time.

Recent changes associated with increased global temperatures have made coastal lagoons susceptible to eutrophication (McGlathery et al. 2001, 2007). Marginal environments such as lagoons, characterized by high nutrient input and longer residence times, are often dominated by stress-tolerant taxa (Hallock 2012), testifying the degrading quality of the habitat. Previous studies have shown that episodic influxes of nutrients under such environmental settings can play a major role in shaping the underlying benthic foraminiferal diversity (Papaspyrou et al. 2013, Rodrigues et al. 2015).

Chilika lagoon $\left(19^{\circ} 28^{\prime}-19^{\circ} 54^{\prime} \mathrm{N}, 85^{\circ} 06^{\prime}-85^{\circ} 35^{\prime} \mathrm{E}\right)$, located on the northwest coast of the Bay of Bengal, is the largest brackish water lagoon in Asia. The lagoon is highly influenced by the northwestern monsoon, which induces increased precipitation along the entire northeastern Indian sub-continent from July to October. The freshwater inflow during the monsoon markedly affects the hydrological conditions, with an increasing watershed area of the lagoon from $704 \mathrm{~km}^{2}$ in pre-monsoon (March to June) to $1020 \mathrm{~km}^{2}$ during the monsoon season (Gupta et al. 2008). The majority of the freshwater influx originates from the unregulated drainage of the western catchment and from the distributaries of the Mahanadi River basin that meet the lagoon in its northern fringes. The lagoon is bordered on its northern and eastern sides by a catchment region of $4406 \mathrm{~km}^{2}$, which provides an additional source of freshwater inflow (Panigrahi et al. 2009). The lagoon is separated from the Bay of Bengal by a sand bar approximately $60 \mathrm{~km}$ long bearing 3 openings, of which 2 were naturally formed in 2008 and 2012 (Sahu et al. 2014), alongside an artificially dredged inlet opened in 2001. Limited marine water inflow from these openings, coupled with the presence of sand bars, limit tidal variation to a negligible amount within the lagoon $(<0.07 \mathrm{~m} ;$ Gupta et al. 2008). The lagoon has another marine connection through the artificially dredged Palur canal in its southernmost region; however, a major controlling factor of Chilika lagoon's hydrology in the absence of diurnal saline influx is the seasonal inflow of freshwater received from the 52 rivers and rivulets that drain into it. The annual average (for the period 1999 to 2007) freshwater influx from these riverine sources has been estimated to be $5.09 \times 10^{9} \mathrm{~m}^{3}$ (Panda \& Mohanty 2008), with approximately $60-80 \%$ contribution from the northeastern rivers (Sahu et al. 2014). During the premonsoon, due to virtually non-existent freshwater inflow from the aforementioned rivers, the saline water-covered area of the lagoon extends to its maximum, whereas during the monsoon, the entire lagoon is converted into a freshwater body (Jeong et al. 2008).

The seasonal dynamics observed in the lagoon can affect the environmental conditions and result in changes in the biotic assemblage composition. On 1 October 1981, the lagoon was declared as a Ramsar site (wetland of international importance). Nutrient dynamics observed in this shallow $(<2 \mathrm{~m})$ water body are influenced by monsoonal precipitation (Nayak \& Behera 2004, Panigrahi et al. 2009), along with physiological factors and carbon dynamics (Muduli et al. 2012, 2013). Previous studies of the lagoon have identified seasonal variations within the phytoplankton (Panigrahi et al. 2009, Srichandan et al. 2015a) and zooplankton (Naik et al. 2008) communities of the water column; however, studies investigating seasonal patterning within the benthic bottom-dwelling communities are not available. Previous reports on the diversity of benthic foraminifers from this lagoon have reported extremely low values (Jayalakshmy \& Rao 2001, Kumar et al. 2015). However, these studies did not consider both the living and dead counterparts, and were based on a limited number of samplings. The present study attempts to address seasonal variability within the biotic assemblage by restricting analysis to only benthic foraminiferal specimens considered to be living at the time of collection. 
The objective of the present work is to study the seasonal variations within the subtidal benthic foraminiferal assemblages of the aforesaid coastal lagoon over a period of 12 mo to generate an understanding of its dynamics in a stressed marginal habitat in the absence of tidal influence.

\section{MATERIALS AND METHODS}

\section{Sediment collection}

Monthly collection of sub-tidal sediments was carried out from 6 stations (Fig. 1, Table 1), selected based on their proximity to potential sources of influx into the Chilika lagoon, for a period of 12 mo from March 2014 until February 2015. Sediment samples were extracted using a Ponar grab (Wild) with an area of $0.025 \mathrm{~m}^{2}$. Schönfeld et al. (2012) mandated that grab samplers should be avoided while sampling in soft-bottom conditions as intact sediments are rarely extracted. Grab collections during the present study were thoroughly inspected and only grabs representing an undisturbed sediment surface were considered for sub-sampling. Sediment subsamples were cored in triplicate from the collected sediment using a push corer with a length of $10 \mathrm{~cm}$ and an inner diameter of 3.5 $\mathrm{cm}$. The topmost $6 \mathrm{~cm}$ from the collected cores were further sub-sectioned into 3 vertical fractions of $0-2 \mathrm{~cm}$, representing the surface sediment, and $2-4 \mathrm{~cm}$ and $4-6 \mathrm{~cm}$, representing sub-surface fractions, in order to determine the vertical distribution of benthic foraminifers. All collected samples were immediately stained with rose bengal (2 $\mathrm{g}$ $\mathrm{1}^{-1}$ ) and fixed with $\mathrm{pH}$-neutral $4 \%$ formaldehyde solution. Formaldehyde was chosen due to its dual utility as preservative and fixative (Schönfeld et al. 2012). Usage of formaldehyde has been reported to decalcify calcareous specimens (Maybury \& Gwynn 1993), hence it was neutralized prior to usage. Distinction between live and dead collected specimens was done based on rose bengal staining of the protoplasm. Overestimation of live density due to the persistence of protoplasm within the test even after the death of the foraminifer is the major drawback of rose bengal staining (Bernhard 2000); however, it still remains the most widely used and advocated methodology due to its inherent simplicity. In investi- gations where foraminifera are studied in relation to prevailing environmental conditions in a marine environment, it has been mandated that only live (rose bengal stained) specimens should be considered (Schönfeld et al. 2012). Fixed sample fractions were stored under dark conditions for $30 \mathrm{~d}$ before undertaking further analyses.

\section{Measurement of in situ environmental conditions}

Environmental conditions of the water column were measured at the time of sediment collection using onboard equipment. Water samples overlaying the sediment were collected by deploying a $5 \mathrm{l}$ Niskin water sampler (General Oceanics) from which salinity was determined using a handheld refractometer and $\mathrm{pH}$ was determined using a $\mathrm{pH}$ meter (Eutech Instruments). Dissolved oxygen (DO) concentrations at the sediment-water interface were measured in situ by positioning the galvanometric probe of a microprocessor-based DO meter (Eutech Instruments) over the sediment surface.
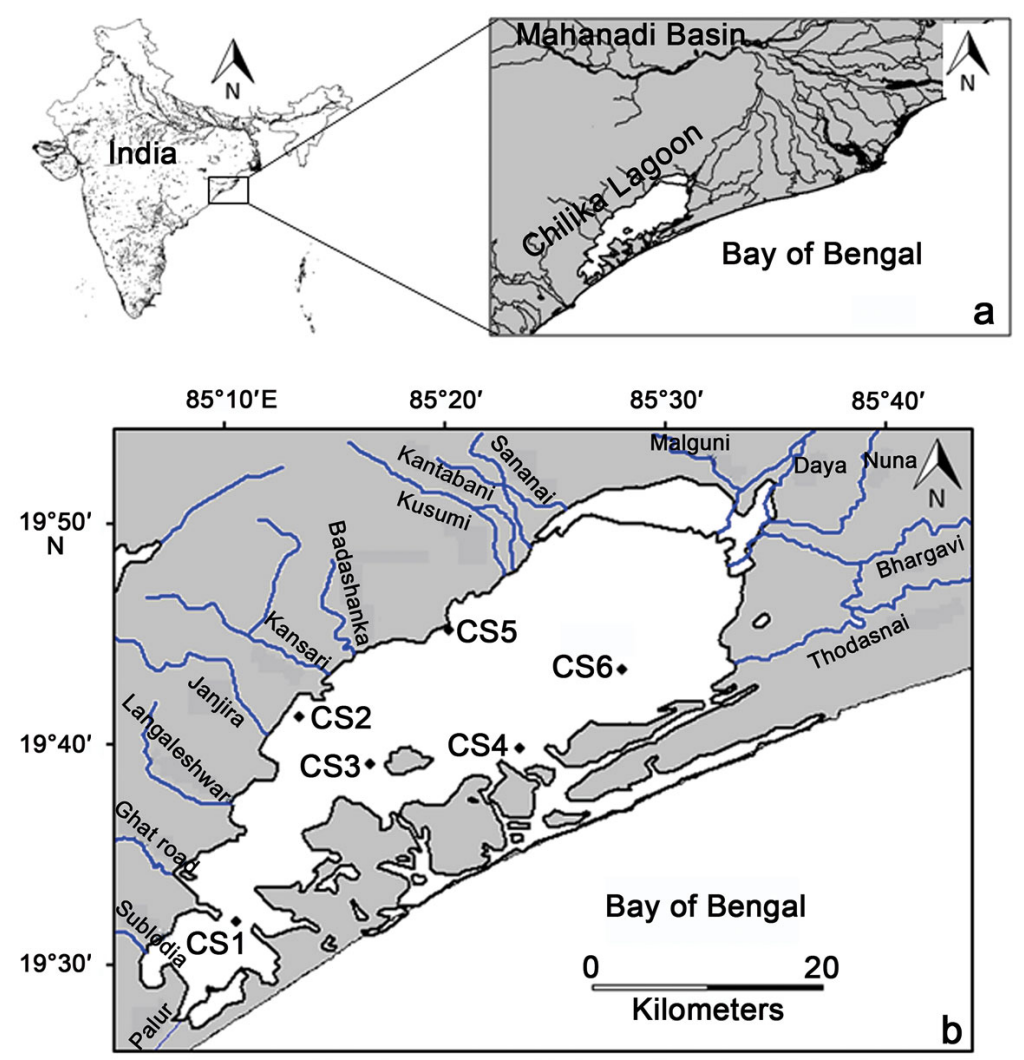

Fig. 1. (a) Location of Chilika lagoon and its major sources of hydrographic influences; the Mahanadi basin and the Bay of Bengal. (b) Location of sampling stations (CS1-CS6) 
Table 1. Location and the potential nature and source of hydrographical influence at each of the sampling stations

\begin{tabular}{|c|c|c|c|}
\hline Stn & Coordinates & $\begin{array}{l}\text { Nature of } \\
\text { probable influence }\end{array}$ & Source of probable influence \\
\hline CS1 & $\begin{array}{l}\mathrm{N} 19^{\circ} 33^{\prime} 22.6^{\prime \prime} \\
\mathrm{E} 85^{\circ} 10^{\prime} 06.4^{\prime \prime}\end{array}$ & Marine & $\begin{array}{l}\text { Palur canal flowing through the lagoon and connecting } \\
\text { to the Bay of Bengal }\end{array}$ \\
\hline $\mathrm{CS} 2$ & $\begin{array}{l}\mathrm{N} 19^{\circ} 43^{\prime} 40.7^{\prime \prime} \\
\mathrm{E} 85^{\circ} 13^{\prime} 04.3^{\prime \prime}\end{array}$ & Freshwater & $\begin{array}{l}\text { Effluent from Balugaon town flowing into the western } \\
\text { catchment }\end{array}$ \\
\hline CS3 & $\begin{array}{l}\mathrm{N} 19^{\circ} 41^{\prime} 39.5^{\prime \prime} \\
\mathrm{E} 85^{\circ} 16^{\prime} 55.5^{\prime \prime}\end{array}$ & Mixed & Adjacent sanctuary islands of the lagoon \\
\hline CS4 & $\begin{array}{l}\mathrm{N} 19^{\circ} 42^{\prime} 02.0^{\prime \prime} \\
\mathrm{E} 85^{\circ} 24^{\prime} 00.0^{\prime \prime}\end{array}$ & Marine & Artificially dredged connection to the Bay of Bengal \\
\hline CS5 & $\begin{array}{l}\mathrm{N} 19^{\circ} 48^{\prime} 51.1^{\prime \prime} \\
\mathrm{E} 85^{\circ} 20^{\prime} 35.3^{\prime \prime}\end{array}$ & Freshwater & $\begin{array}{l}\text { Outfall of the Kusumi, Kantabani and Sonanai Rivers } \\
\text { from the western catchment }\end{array}$ \\
\hline CS6 & $\begin{array}{l}\mathrm{N} 19^{\circ} 44^{\prime} 34.8^{\prime \prime} \\
\mathrm{E} 85^{\circ} 25^{\prime} 27.6^{\prime \prime}\end{array}$ & Mixed & $\begin{array}{l}\text { Outfall of the distributaries from the Mahanadi basin and the } \\
\text { artificially dredged connection to Bay of Bengal }\end{array}$ \\
\hline
\end{tabular}

\section{Measurement of dissolved nutrient concentrations}

Concentrations of dissolved nutrients, i.e. nitrate $\left(\mathrm{NO}_{3}{ }^{-}\right)$, ortho-phosphate $\left(\mathrm{PO}_{4}{ }^{3-}\right)$, ammonium $\left(\mathrm{NH}_{4}{ }^{+}\right)$ and silicate $\left(\mathrm{SiO}_{4}{ }^{2-}\right)$, were measured from the water overlaying the sediment; $125 \mathrm{ml}$ of water was collected and transferred to an amber-colored bottle, fixed immediately using pH-neutral $2 \%$ formaldehyde and transported to the laboratory as per published protocols (Choudhury et al. 2015). At the laboratory, the collected water samples were immediately passed through a $0.45 \mu \mathrm{m}$ nylon filter (MerckMillipore) in order to remove suspended particulate matter, and the concentrations of dissolved nutrients were determined spectrophotometrically (U-2900UV/ VIS Spectrophotometer, Hitachi). Dissolved $\mathrm{NO}_{3}{ }^{-}$ concentrations were subsequently measured following published methods (Finch et al. 1998). Likewise, dissolved $\mathrm{PO}_{4}{ }^{3-}$ and $\mathrm{SiO}_{4}{ }^{2-}$ levels were measured spectrophotometrically by acid-molybdate (Strickland \& Parsons 1972) and ammonium molybdate (Turner et al.1998) methods, respectively. Concentrations of dissolved $\mathrm{NH}_{4}{ }^{+}$were also determined following the potassium ferrocyanide method (Liddicoat et al. 1975).

\section{Precipitation data}

Monthly data of precipitation in the region were obtained from the Orissa government's meteorological database (www.orissa.gov.in/disaster/src/RAINFALL1/RAINFALL.html). For every month, the entire state's precipitation values were considered to provide data about the seasonal variation in rainfall.

\section{Benthic foraminiferal analyses}

Estimation of stained benthic foraminiferal diversity from Chilika was carried out by analyzing each collected fraction separately. A total of $10 \mathrm{~cm}^{3}$ of sediment from each fraction was wet-sieved under a jet of freshwater through mesh sizes of 500 and $63 \mu \mathrm{m}$. The collected residue in both mesh sizes was observed under a stereozoom microscope (Zeiss Stemi DV4, Carl Zeiss AG) by wet splitting. Residues $\geq 500 \mu \mathrm{m}$ were observed for larger foraminiferal tests while $\geq 63 \mu \mathrm{m}$ residues were checked for meiobenthic counterparts. Specimens bearing stained cytoplasm up to the penultimate chamber were considered to be live at the time of collection. Identification of foraminiferal taxa was performed up to genus level following Loeblich \& Tappan (1987). Species-level identification was performed by wet-picking representative specimens from $>63 \mu \mathrm{m}$ sieved fractions and imaging them under a field emission scanning electron microscope (FESEM, Zeiss SUPRA55VP Carl Zeiss AG). Such specimens were initially stored in 1:1 isopropyl alcohol solution overnight for dehydration, and were then placed on aluminum stab and coated with gold-palladium for FESEM imaging. Further identification was carried out by following local literature and published taxonomic keys (Devi \& Rajashekhar 2009, Hayward et al. 2004).

\section{Statistical analyses}

To identify spatial variability within the observed benthic foraminifera on both horizontal and vertical scales, a 2-way ANOSIM approach was applied 
using Bray-Curtis similarity as a distance matrix with 9999 permutations. The analysis was performed by assigning numerical codes to $\log (x+1)$ transformed data from each separate sample considered factorwise with stations of collection as the first factor and depth of collection as the second factor. Classification of foraminiferal assemblages based on season was investigated by applying a hierarchical clustering method. The unweighted paired group method with arithmetic mean (UPGMA) algorithm was used to construct clusters based on the mean distance between each studied fraction based on Bray-Curtis similarity. Prior to hierarchical clustering, SIMPER analysis was performed by coding the samples according to their season of collection to determine which benthic foraminiferal species contributed most to the observed seasonal differences. Foraminiferal species having a contribution of $>10 \%$ to the observed variation were only considered during hierarchical clustering to increase the robustness of the method. A Monte Carlo test (1000 permutations) was performed to calculate the replication percentages of each cluster. For all analyses, square root-transformed values of absolute abundance in $10 \mathrm{~cm}^{3}$ for each foraminiferal species was used following $\log (x+1)$ normalization to address non-normal data and observed zero values. The obtained clusters were re-examined using the Raup-Crick similarity measure to test their reproducibility. Identification of any potential environmental parameter impacting the assemblage dynamics of foraminifera was performed by correlating the observed total abundance, diversity and species-wise abundance with measured environmental parameters. All statistical tests, along with the calculation of Shannon diversity $\left(H^{\prime}\right)$, were calculated using the PaST software package v.3.09 (Hammer et al. 2001).

\section{RESULTS}

\section{Precipitation and environmental conditions}

In situ environmental conditions recorded from the bottom water representing each station are detailed in Fig. 2 along with the total regional precipitation during the respective sampling period. Maximum rainfall was recorded during the monsoon month of July 2014 (15059 mm), while December 2014 records present the least amount $(23 \mathrm{~mm})$ of rainfall during the study period. The monsoon months (July-October 2014) recorded a total of $39053 \mathrm{~mm}$ in precipitation compared with pre-monsoon and post-monsoon val-
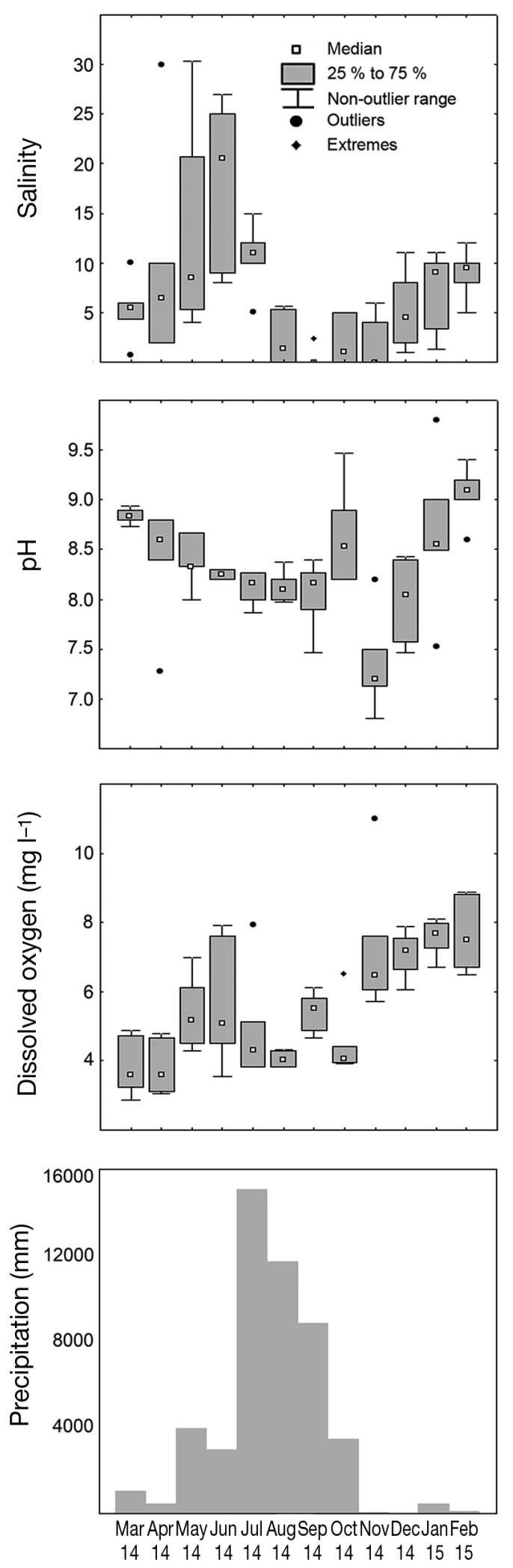

Fig. 2. Variation in the environmental parameters in the water column of Chilika lagoon with respect to precipitation during the study period 
ues of 8388 and $4111 \mathrm{~mm}$, respectively. Recorded salinity values were at a minimum (1.6) during September 2014, and at 5 out of 6 sampling stations, the values were zero. Mean salinity values were highest (18.3) during pre-monsoon (March-June 2014) in June 2014. Bottom-water pH values were in the basic range of 7.3 to 9.1. DO concentrations displayed higher values during the post-monsoon (November 2014-February 2015), with the highest values recorded for the February 2015 collection. DO values during pre-monsoon and monsoon were in the range of 2.9-7.9 and 3.8-7.9 $\mathrm{mg} \mathrm{l}^{-1}$, respectively.

\section{Dissolved nutrient concentrations}

Measured dissolved nutrient concentrations are presented in Fig. 3. Dissolved nitrate $\left(\mathrm{NO}_{3}{ }^{-}\right)$values ranged between 16 and $95.3 \mu \mathrm{M}$ in the bottom water. Higher variation within the stations' $\mathrm{NO}_{3}{ }^{-}$concentrations were observed during the pre-monsoon months, while the values exhibited less spatial heterogeneity in subsequent samplings. Dissolved phosphate $\left(\mathrm{PO}_{4}{ }^{3-}\right)$ concentrations varied within a range of 0 to $3.9 \mu \mathrm{M}$, with lower values recorded during late monsoon to post-monsoon months. Dissolved ammonium $\left(\mathrm{NH}_{4}{ }^{+}\right)$ concentrations ranged between 0 and $12.7 \mu \mathrm{M}$. The $\mathrm{NH}_{4}{ }^{+}$concentrations were lowest during March 2014, when 5 sampling stations had values lower than the detection limit of the methodology used. Silicate $\left(\mathrm{SiO}_{4}{ }^{2-}\right)$ concentration displayed a wider range of variability with time, having lower values during premonsoon, gradually increasing during monsoon and lowering during the post-monsoon. Values of dissolved $\mathrm{SiO}_{4}{ }^{2-}$ displayed a wider range, with a minimum value of $5 \mu \mathrm{M}$ and a maximum of $377.5 \mu \mathrm{M}$.

\section{Foraminiferal analyses}

Assessment of benthic foraminifera presumed to be living at the time of collection was carried out by analyzing 216 sediment fractions, with 72 fractions from each depth profile $(0-2,2-4$ and $4-6 \mathrm{~cm})$. No large $(>500 \mu \mathrm{m})$ benthic foraminifera were observed. A total of 1344 stained specimens (per $10 \mathrm{~cm}^{3}$ sediment volume) were observed in the $>63 \mu \mathrm{m}$ sieved fractions that were considered as living. Out of the sediment fractions analyzed from the surface $0-2 \mathrm{~cm}$ fraction, 52 contained stained specimens, while 27 out of the 2-4 cm fraction bore such individuals. In the $4-6 \mathrm{~cm}$ fraction samples, no live specimens were encountered. FESEM analyses of representative live
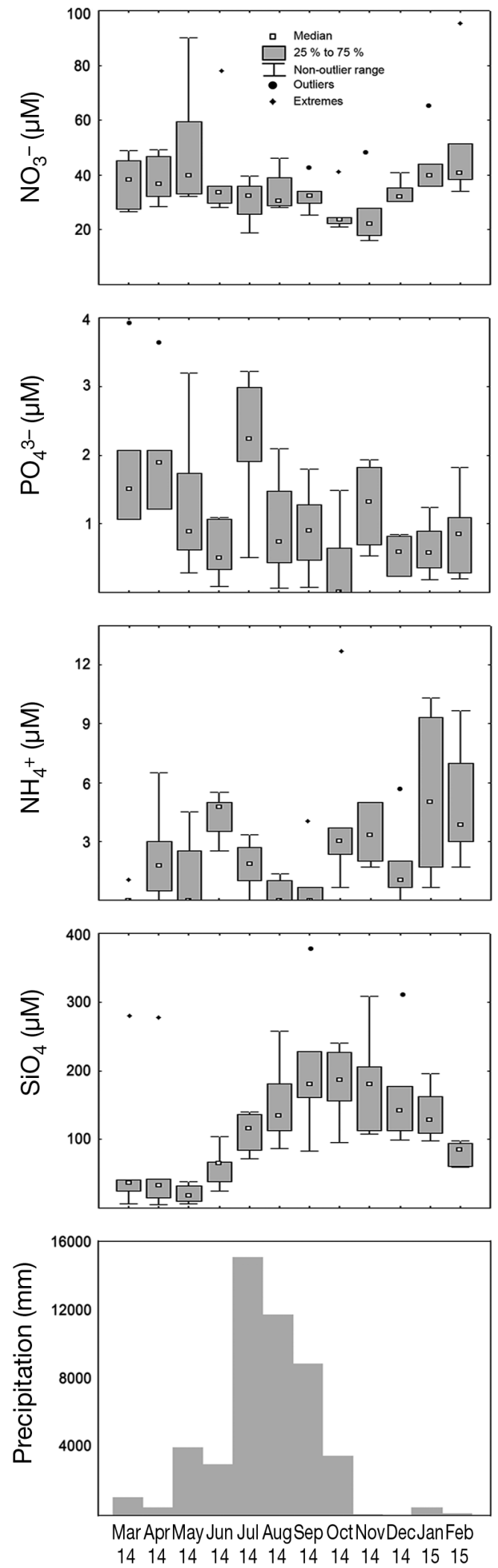

Fig. 3. Variation in the dissolved nutrient concentrations in the water column of Chilika lagoon with respect to precipitation during the study period 
Fig. 4. Field emission scanning electron microscopy (FESEM) of (a) Quinqueloculina seminulum d'Orbigny, 1826, (b) Trochammina inflata Montagu, 1808, (c) Textularia agglutinans d'Orbigny, 1839, (d) Ammodiscus sp., (e) Miliammina obliqua Herron-Allen and Earland, 1930, (f) Miliammina fusca Brady, 1870, (g) Ammobaculites agglutinans d'Orbigny, 1846, (h) Ammotium salsum Cushman and Brönnimann, 1948, and (i) Ammomarginulina sp.

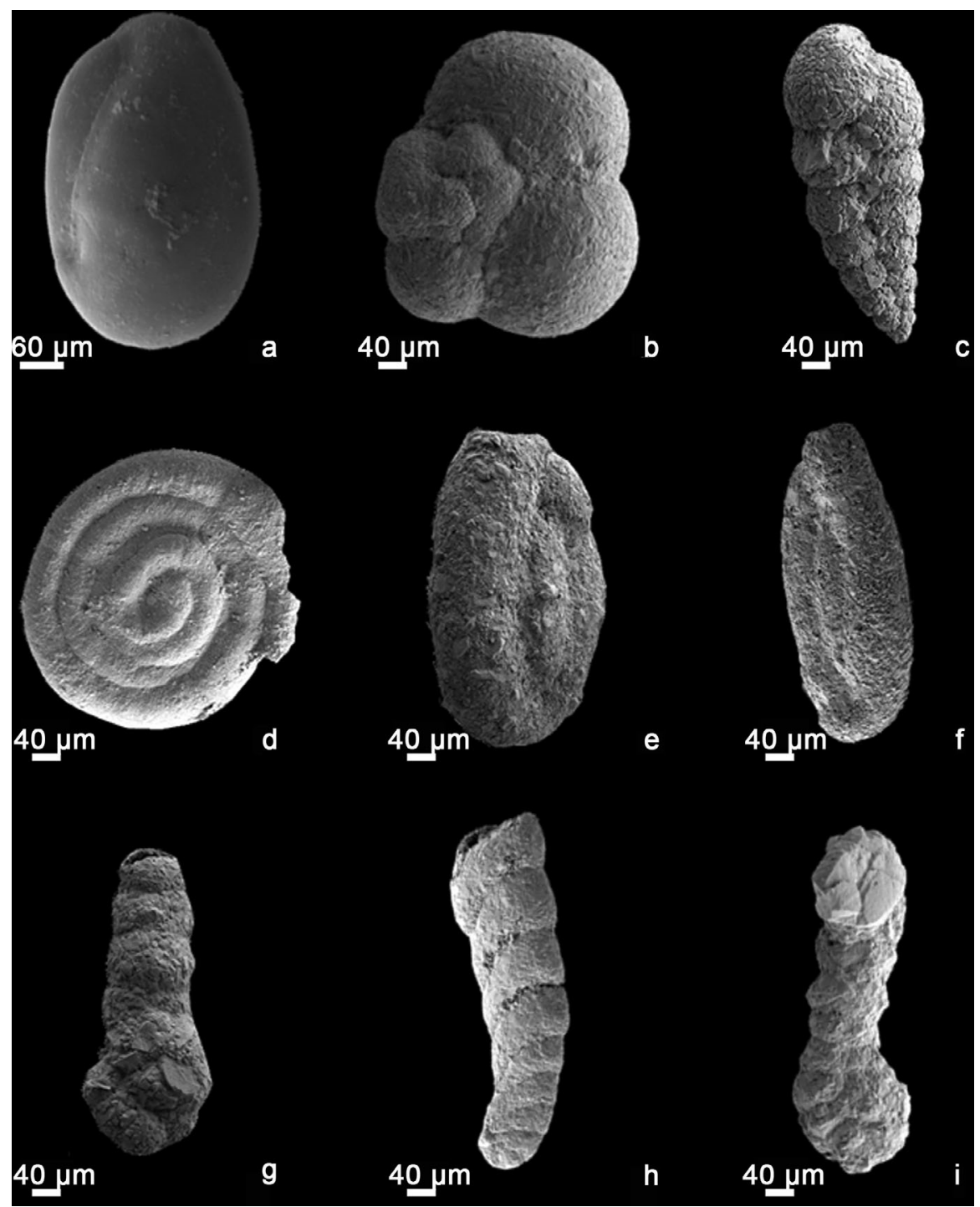

small prolocular chamber. Ammonia T6 was characterized by pores having a larger diameter and fewer chambers in the final whorl, synonymous with $A$. aomoriensis as stated earlier by Hayward et al. (2004). However, the species showing similarity to Ammonia T6 did not correspond with any valid synonymous species name. Observed specimens belonging to the genus Ammomarginulina often had their last chambers broken and hence were not suitable for identification to species level, and have been presented as Ammomarginulina sp.

In Fig. 6, mean values of $\log$ abundance in $10 \mathrm{~cm}^{3}$ of sediment $(\log A)$ and Shannon diversity index $\left(H^{\prime}\right)$ values from the surface $0-2 \mathrm{~cm}$ and sub-surface $2-4 \mathrm{~cm}$ fractions are compared. The highest values of abundance in the $0-2 \mathrm{~cm}$ fraction were observed in December 2014. In Table 2, the detailed values of the final whorl, absence of a secondary calcite and a 


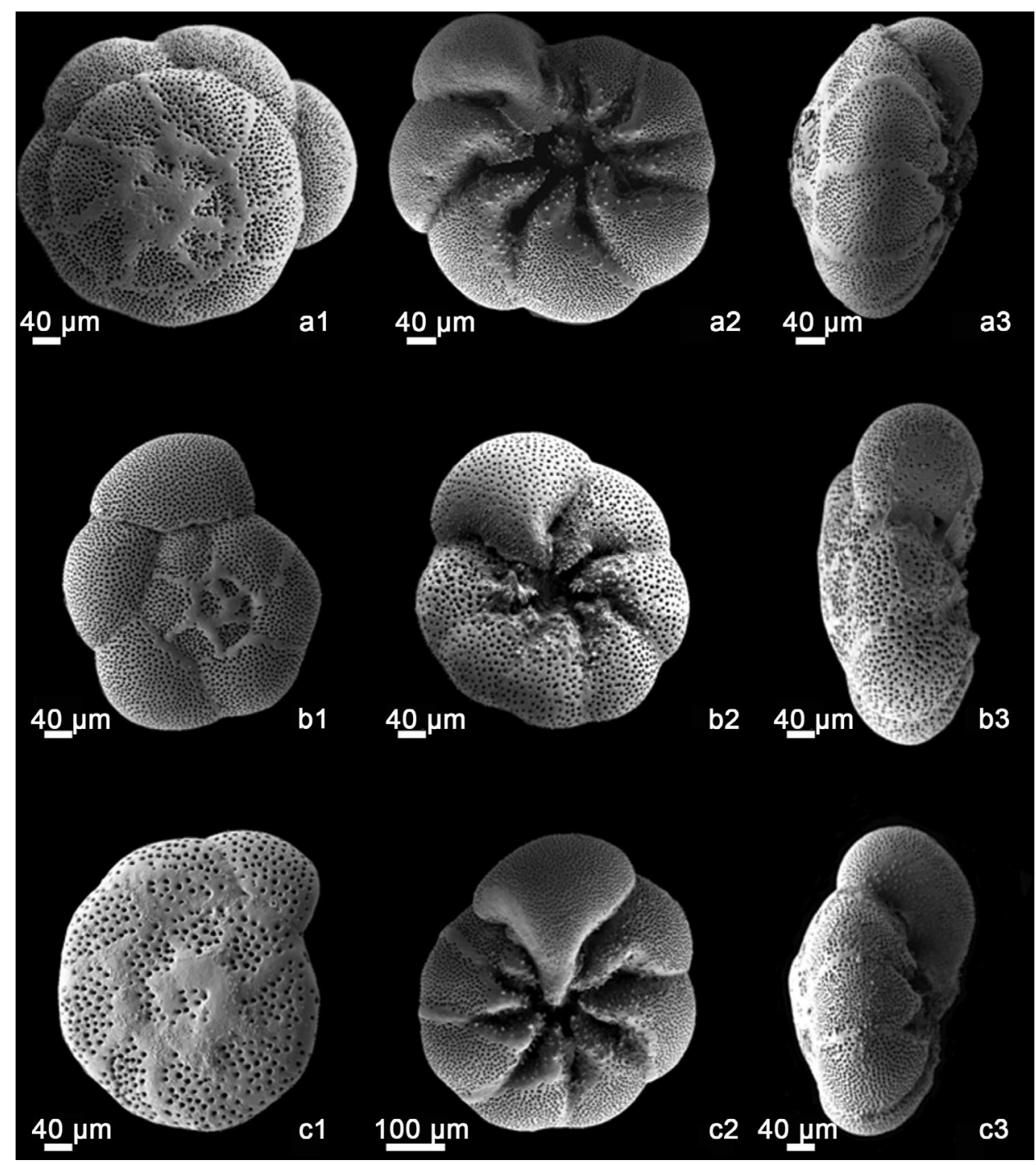

Fig. 5. FESEM of (a) Ammonia T2; a1: spiral view, a2: umbilical view, a3: profile view; (b) Ammonia T6; b1: spiral view, b2: umbilical view, b3: profile view; and (c) Ammonia T10; c1: spiral view, c2: umbilical view, c3: profile view foraminiferal abundance across depth fractions from the 6 studied stations are presented. In December 2014, the major contributors to number of living specimens were Ammonia T2 and Miliammina obliqua. While Ammonia T2 was present in a comparatively moderate number $\left(24 / 10 \mathrm{~cm}^{3}\right)$ in the surface fraction of the CS3 station, $M$. obliqua was considerably higher in both the surface $\left(33 / 10 \mathrm{~cm}^{3}\right)$ and subsurface $\left(24 / 10 \mathrm{~cm}^{3}\right)$ fractions of CS5. Dominance of $M$. obliqua at CS5 continued in January 2015, where it absolutely dominated the living assemblage (surface: $27 / 10 \mathrm{~cm}^{3}$, sub-surface: $15 / 10 \mathrm{~cm}^{3}$ ). Mean $H^{\prime}$ was low during this month (Fig. 6). Ammonia T2 was most frequently observed in 55 out of 79 samples across the study period, but the species was mostly restricted to the $0-2 \mathrm{~cm}$ fraction. The highest abundance of Ammonia T2 was recorded from CS5 in May 2014 in the surface fraction $\left(74 / 10 \mathrm{~cm}^{3}\right)$. The value was the highest for any individual species observed during the study. Ammonia T10 was also high in abundance $\left(51 / 10 \mathrm{~cm}^{3}\right)$ in the same sample $(0-2 \mathrm{~cm}$ of CS5, May 2014). Abundance of the 2-4 cm assemblage was higher in March 2014 as Ammomarginulina sp. was present in higher proportions in the subsurface fraction at CS3 $\left(14 / 10 \mathrm{~cm}^{3}\right)$ and CS5 $\left(11 / 10 \mathrm{~cm}^{3}\right)$. The stations CS3 and CS5 continued to display a dominance of Ammomarginulina sp. in April and May 2014.

The observed $H^{\prime}$ values in the surface fraction ranged between 0.29 and 1.49 in samples collected from CS5 in December 2014 and CS4 in October 2014, respectively, while 21 out of 52 samples bearing live specimens were represented by single species. The $2-4 \mathrm{~cm}$ subsurface fraction displayed lower values of diversity, ranging from 0.47 (CS5 in May 2014 ) to 1.28 (CS1 in July 2014). The highest value of diversity observed at CS1 in the July 2014 collection 
Table 2. Correlation analysis results between observed total abundance and diversity and species-specific abundance (N) and relative diversity (\%) with measured environmental parameters across the depth profile. Significant values $(p \leq 0.05)$ are in bold

\begin{tabular}{|c|c|c|c|c|c|c|c|c|c|c|c|c|c|c|}
\hline Depth fraction 0-2 cm & \multicolumn{2}{|c|}{ Salinity } & \multicolumn{2}{|c|}{$\mathrm{pH}$} & \multicolumn{2}{|c|}{ DO } & \multicolumn{2}{|c|}{ Nitrate } & \multicolumn{2}{|c|}{ Phosphate } & \multicolumn{2}{|c|}{ Silicate } & \multicolumn{2}{|c|}{ Ammonium } \\
\hline Total abundance $/ 10 \mathrm{~cm}^{3}$ & \multicolumn{2}{|c|}{0.04} & \multicolumn{2}{|c|}{-0.09} & \multicolumn{2}{|c|}{0.10} & \multicolumn{2}{|c|}{0.26} & \multicolumn{2}{|c|}{-0.06} & \multicolumn{2}{|c|}{-0.08} & \multicolumn{2}{|c|}{0.03} \\
\hline \multirow[t]{2}{*}{ Shannon diversity $\left(H^{\prime}\right)$} & \multicolumn{2}{|c|}{-0.05} & \multicolumn{2}{|c|}{-0.04} & \multicolumn{2}{|c|}{-0.16} & \multicolumn{2}{|c|}{-0.05} & \multicolumn{2}{|c|}{0.11} & \multicolumn{2}{|c|}{-0.08} & \multicolumn{2}{|c|}{0.06} \\
\hline & $\mathrm{N}$ & $\%$ & $\mathrm{~N}$ & $\%$ & $\mathrm{~N}$ & $\%$ & $\mathrm{~N}$ & $\%$ & $\mathrm{~N}$ & $\%$ & $\mathrm{~N}$ & $\%$ & $\mathrm{~N}$ & $\%$ \\
\hline Ammodiscus sp. & 0.05 & 0.05 & -0.17 & -0.17 & 0.13 & 0.13 & -0.01 & -0.01 & -0.10 & -0.10 & -0.01 & -0.01 & 0.02 & 0.02 \\
\hline Trochammina inflata & 0.30 & 0.13 & -0.12 & -0.16 & -0.09 & -0.11 & -0.07 & -0.06 & -0.05 & -0.07 & -0.11 & 0.00 & 0.09 & 0.09 \\
\hline Ammotium salsum & -0.01 & 0.00 & 0.00 & 0.01 & 0.16 & 0.16 & -0.11 & -0.12 & -0.02 & -0.05 & -0.05 & -0.06 & 0.08 & 0.09 \\
\hline Textularia agglutinans & -0.11 & -0.14 & -0.04 & -0.24 & -0.09 & -0.03 & -0.17 & -0.14 & 0.15 & 0.10 & 0.24 & 0.22 & -0.04 & 0.03 \\
\hline Ammobaculites agglutinans & 0.07 & 0.09 & -0.04 & -0.04 & -0.12 & -0.12 & -0.18 & -0.18 & 0.28 & 0.29 & -0.01 & -0.02 & -0.13 & -0.11 \\
\hline Ammomarginulina sp. & -0.12 & -0.12 & -0.02 & -0.02 & -0.02 & -0.02 & 0.05 & 0.05 & -0.09 & -0.09 & 0.16 & 0.16 & -0.11 & -0.11 \\
\hline Ammonia T2 & 0.00 & -0.04 & -0.16 & -0.17 & 0.06 & -0.02 & 0.33 & 0.20 & -0.06 & 0.03 & -0.02 & 0.06 & -0.08 & -0.03 \\
\hline Ammonia T10 & 0.16 & 0.25 & -0.09 & -0.06 & 0.06 & -0.24 & 0.21 & -0.03 & -0.05 & -0.01 & -0.13 & -0.09 & 0.05 & 0.11 \\
\hline Ammonia T6 & -0.14 & -0.02 & 0.02 & 0.13 & -0.09 & -0.15 & 0.12 & -0.10 & 0.00 & 0.11 & -0.09 & -0.19 & -0.07 & -0.05 \\
\hline Quinqueloculina seminula & 0.00 & -0.03 & 0.11 & 0.13 & -0.23 & -0.20 & -0.07 & -0.05 & 0.23 & 0.14 & -0.21 & -0.19 & -0.15 & -0.16 \\
\hline Miliammina obliqua & -0.13 & -0.10 & 0.21 & 0.24 & 0.20 & 0.23 & 0.13 & 0.16 & -0.07 & -0.07 & 0.01 & -0.02 & 0.30 & 0.34 \\
\hline Miliammina fusca & -0.17 & -0.17 & 0.03 & 0.03 & -0.02 & 0.00 & -0.06 & -0.05 & -0.13 & 0.00 & 0.16 & 0.15 & -0.08 & 0.02 \\
\hline Depth fraction 2-4 cm & & linity & & $\mathrm{H}$ & & $\mathrm{O}$ & Nit & ate & Pho & phate & Sili & cate & $\mathrm{Amn}$ & Ionium \\
\hline Total abundance $/ 10 \mathrm{~cm}^{3}$ & \multirow{2}{*}{\multicolumn{2}{|c|}{$\begin{array}{l}-0.11 \\
-0.02\end{array}$}} & \multirow{2}{*}{\multicolumn{2}{|c|}{$\begin{array}{l}0.03 \\
0.04\end{array}$}} & \multirow{2}{*}{\multicolumn{2}{|c|}{$\begin{array}{l}0.19 \\
0.08\end{array}$}} & \multirow{2}{*}{\multicolumn{2}{|c|}{$\begin{array}{l}0.10 \\
0.08\end{array}$}} & & 00 & -0 & 03 & & .02 \\
\hline \multirow[t]{2}{*}{ Shannon diversity $\left(H^{\prime}\right)$} & & & & & & & & & & 10 & & 04 & & .11 \\
\hline & $\mathrm{N}$ & $\%$ & $\mathrm{~N}$ & $\%$ & $\mathrm{~N}$ & $\%$ & $\mathrm{~N}$ & $\%$ & $\mathrm{~N}$ & $\%$ & $\mathrm{~N}$ & $\%$ & $\mathrm{~N}$ & $\%$ \\
\hline Ammodiscus sp. & 0.06 & 0.07 & -0.18 & -0.16 & 0.16 & 0.21 & -0.02 & -0.04 & -0.08 & -0.07 & -0.02 & -0.05 & 0.02 & 0.06 \\
\hline Ammotium salsum & -0.02 & 0.01 & -0.08 & -0.08 & 0.12 & 0.14 & -0.05 & -0.05 & 0.14 & 0.17 & 0.02 & 0.01 & -0.12 & -0.11 \\
\hline Textularia agglutinans & 0.02 & 0.02 & 0.06 & 0.06 & 0.08 & 0.08 & 0.02 & 0.02 & 0.02 & 0.02 & 0.06 & 0.06 & -0.08 & -0.08 \\
\hline Ammobaculites agglutinans & 0.02 & -0.01 & -0.07 & -0.18 & 0.17 & 0.13 & -0.05 & -0.08 & -0.06 & -0.02 & 0.13 & 0.13 & -0.02 & 0.01 \\
\hline Ammomarginulina sp. & 0.05 & 0.25 & 0.12 & 0.09 & -0.06 & -0.06 & 0.19 & 0.10 & 0.14 & 0.15 & -0.35 & -0.35 & -0.09 & 0.05 \\
\hline Ammonia T2 & -0.16 & -0.13 & 0.05 & -0.01 & -0.03 & -0.11 & 0.04 & -0.01 & -0.03 & -0.08 & 0.13 & 0.29 & -0.10 & 0.04 \\
\hline Ammonia T10 & -0.19 & -0.22 & -0.05 & 0.04 & 0.01 & -0.03 & -0.02 & -0.05 & 0.00 & -0.01 & 0.15 & 0.31 & -0.16 & -0.13 \\
\hline Ammonia T6 & -0.08 & -0.08 & 0.02 & 0.02 & 0.13 & 0.13 & -0.04 & -0.04 & -0.05 & -0.05 & -0.01 & -0.01 & 0.14 & 0.14 \\
\hline Miliammina obliqua & -0.09 & -0.10 & 0.15 & 0.22 & 0.24 & 0.22 & 0.09 & 0.16 & -0.01 & -0.01 & -0.02 & 0.02 & 0.24 & 0.28 \\
\hline Miliammina fusca & 0.02 & 0.07 & 0.11 & 0.08 & 0.12 & 0.21 & 0.09 & 0.04 & 0.00 & -0.01 & 0.10 & -0.04 & -0.02 & 0.02 \\
\hline
\end{tabular}

was due to the occurrence of a high number of species (5) in the 2-4 cm fraction. In the pre-monsoon months (March-June), $H^{\prime}$ ranged from 0 to 1.09 in the surface fraction as samples had a greater dominance of Ammonia T2 and T10, with samples with single-species dominance displaying a zero value of $H^{\prime}$. The subsurface fraction for the pre-monsoon months displayed a range of 0 to 0.97 , with higher median values in March 2014 as compared with its surface fraction counterpart. The increased diversity values in the $2-4 \mathrm{~cm}$ fraction were due to the higher abundance of Ammomarginulina sp. observed in that month (Table 3). The monsoon months displayed decreased median values of $H^{\prime}$ in both fractions as the abundance of live specimens also decreased during this time period. However, as mentioned earlier, the highest value of surface diversity was also noted during this period. During the post-monsoon months, the highest median $H^{\prime}$ values were observed in October 2014, after which the values continued to decrease in the surface fraction. In the subsurface fraction, live specimens were found in only a few samples. The increased presence of $M$. obliqua at CS5 in January 2015 was also reflected in the diversity pattern. To test the spatial variation in the living foraminiferal population within the lagoon in both the horizontal and vertical profiles, 2-way ANOSIM was performed by coding samples bearing live foraminiferal specimens according to their station and depth of collection. The test revealed the foraminiferal assemblage to be significantly different across the 6 stations ( $p=0.0017, R=0.058)$ and across the 2 depth profiles ( $p=0.0001, R=0.151)$. Seasonal variation among the samples was initially investigated by SIMPER analysis to determine which species contributed most to seasonal variations. Table 4 


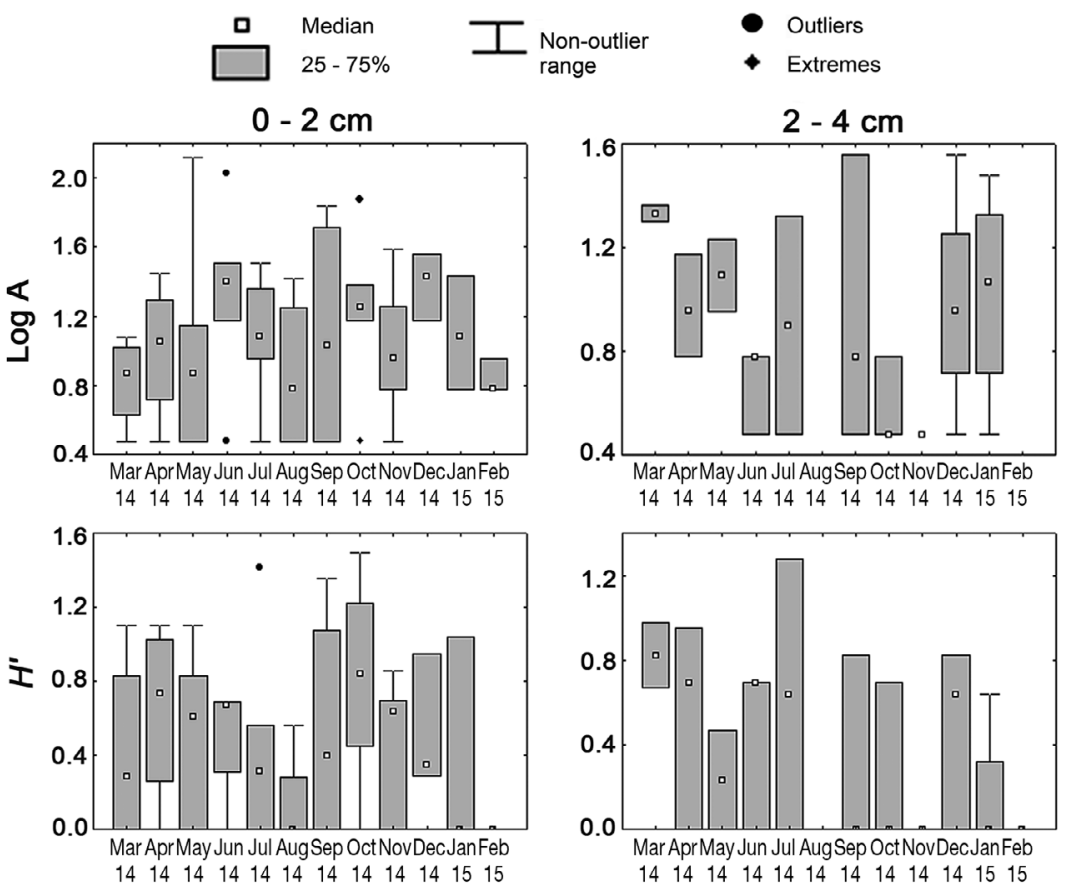

Fig. 6. Variation in the $\log$ abundance $(\log A)$ and Shannon diversity $\left(H^{\prime}\right)$ of the live benthic foraminiferal population

shows the contribution of each species to the dissimilarity percentages observed between seasons. The dissimilarity percentage observed among the seasons was higher between pre-monsoon and post-monsoon samples $(77.55 \%)$ compared with percentages between pre-monsoon and monsoon samples $(70.96 \%)$ and monsoon and post-monsoon samples $(75.08 \%)$. The maximum contribution to observed dissimilarity originated from Ammonia T2 (25.67-28.74) and Ammonia T10 (19.8-23.49).

SIMPER analysis revealed 4 species, Ammonia T2, Ammonia T10, Ammomarginulina sp. and M. obli$q u a$, to be the major contributors to observed seasonal dissimilarities (Table 4). The total number of individuals represented by the above species from the $0-2$ and $2-4 \mathrm{~cm}$ fractions month-wise is shown in Fig. 7. Ammonia T2 and Ammonia T10, which contributed most to observed dissimilarity among the seasons (Table 4), showed a higher abundance in the 0-2 cm fraction in May 2014 compared with the other months. The abundance of Ammonia T2 was relatively higher in the surface fraction compared with other species, while both representatives of the genus were present sporadically in the subsurface fraction with Ammonia T2 being more abundant. Ammomarginulina sp., which had a higher contribution to dissimilarities between pre-monsoon 2014 and other seasons (Table 4), showed increased abundance during March-May 2014 in the 2-4 cm fraction (Fig. 7). Miliammina obliqua, the fourth species to show $>10 \%$ contribution to observed dissimilarities, displayed the highest abundance in December 2014 across both the sediment fractions and was entirely absent during the pre-monsoon months of March-June 2014.

A hierarchical clustering was performed using the aforementioned 4 species to determine any grouping of samples based on station, month or depth of collection (Fig. 8). Five main clusters were observed with the Monte-Carlo test, and clusters showing replication values $>20 \%$ are shown in Fig. 8. Cluster I comprised samples with absolute dominance of Ammomarginulina sp. and samples representing the 2-4 cm fraction from 2 pre-monsoon months, restricted to the CS1, CS3 and CS6 stations. Cluster II was dominated by $M$. obliqua and comprised both depth fractions collected from CS5 in November and December 2014. Samples having an equal composition of Ammonia T2 and Ammonia T10 formed Cluster III, which comprised mostly surface $0-2 \mathrm{~cm}$ samples. Sub-clusters within Cluster III did not present any seasonal grouping. Cluster IV was mostly composed of samples that had a higher or absolute abundance of Ammonia T2. A sub-cluster within Cluster IV was represented by samples with a presence of Ammomarginulina sp. alongside Ammonia T2 and composed almost entirely of samples from the $2-4 \mathrm{~cm}$ fraction. Spatial patterns within Clusters III and IV were not prominent due to the ubiquitous presence of Ammonia T2 across the lagoon. Cluster V comprised samples with a greater contribution from Ammonia T10. Samples from both the 0-2 and 2-4 $\mathrm{cm}$ fractions of stations CS4 and CS6 mostly formed this cluster. Seasonal grouping within Cluster V was also absent as the samples were represented by all 3 seasons.

Table 3. Number (in boxes) and relative abundance (grey shading) of foraminiferal specimens observed for each species from each collected sample in $10 \mathrm{~cm}^{3}$ volume of sediment. The dashed lines denote the 6 stations from where sampling was carried out (see key) 


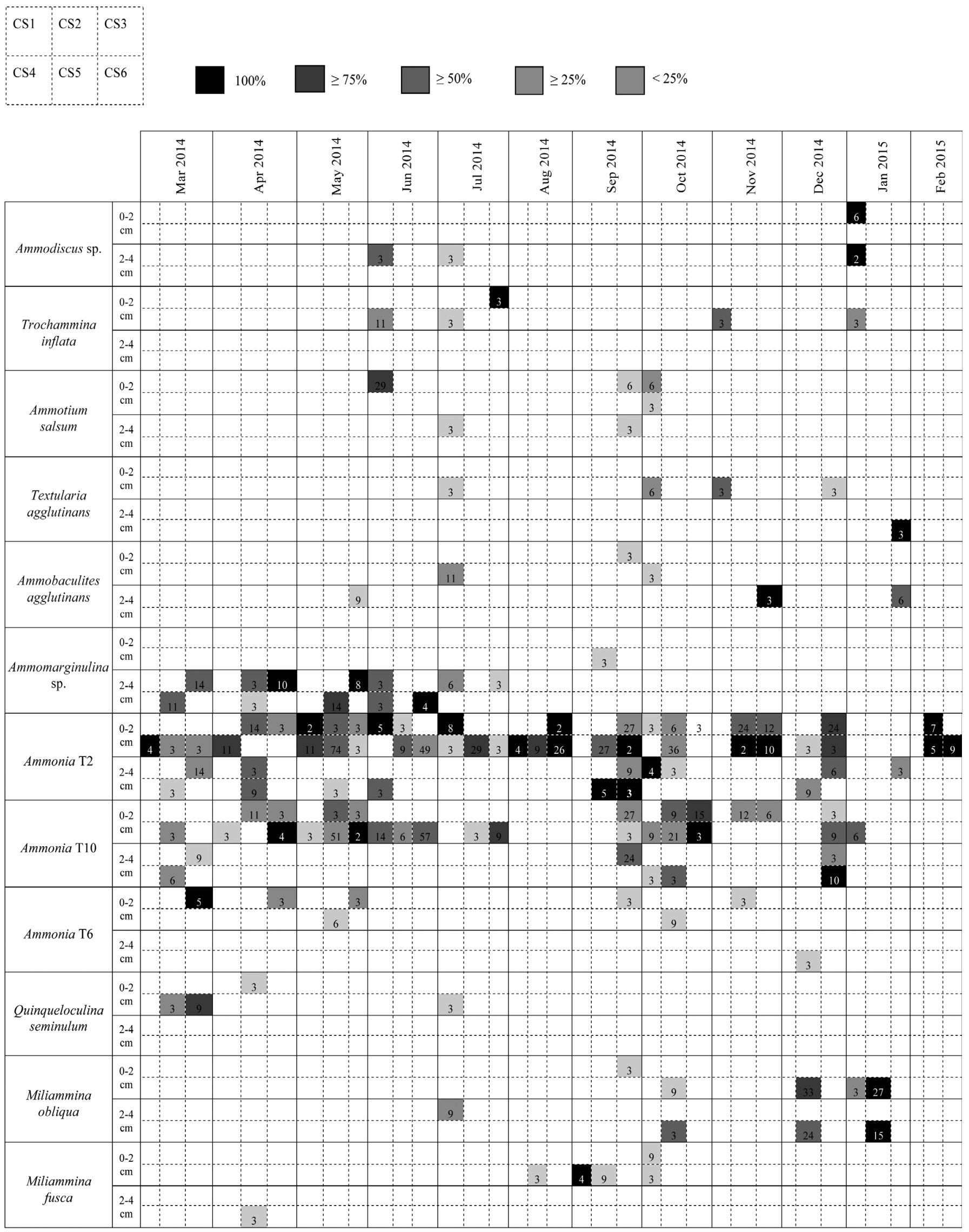


Table 4. Results of the SIMPER analysis performed using PaST v.3.09. Bold values indicate $>10 \%$ contribution of the particular species to the observed percentage of dissimilarity between the studied seasons. Mons: monsoon; 14: 2014, 15: 2015

\begin{tabular}{|lccc|}
\hline & $\begin{array}{c}\text { Pre-mons.- } \\
\text { mons. 14 }\end{array}$ & $\begin{array}{c}\text { Mons. 14- } \\
\text { post-mons. 14/15 }\end{array}$ & $\begin{array}{c}\text { Post-mons. 14/15 } \\
\text {-pre-mons. 14 }\end{array}$ \\
\cline { 2 - 4 } $\begin{array}{l}\text { Dissimilarity (\%) } \\
\text { Species-wise contribution (\%) }\end{array}$ & 70.96 & 75.08 & 77.55 \\
Ammonia T2 & $\mathbf{2 7 . 6 5}$ & $\mathbf{2 8 . 7 4}$ & $\mathbf{2 5 . 6 7}$ \\
Ammonia T10 & $\mathbf{2 3 . 4 9}$ & $\mathbf{1 9 . 8}$ & $\mathbf{1 9 . 8 4}$ \\
Ammomarginulina sp. & $\mathbf{1 5 . 9 1}$ & 3.13 & $\mathbf{1 3 . 9}$ \\
Miliammina obliqua & 3.48 & $\mathbf{1 4 . 0 8}$ & $\mathbf{1 1 . 3 4}$ \\
Miliammina fusca & 6.15 & 6.87 & 2.37 \\
Ammodiscus sp. & 1.76 & 6.09 & 6.12 \\
Ammonia T6 & 5.12 & 2.38 & 4.95 \\
Ammotium salsum & 5.65 & 3.49 & 2.16 \\
Trochammina inflata & 3.51 & 4.18 & 3.44 \\
Ammobaculites agglutinans & 2.16 & 5.38 & 3.34 \\
Textularia agglutinans & 1.45 & 5.25 & 3.88 \\
Quinqueloculina seminula & 3.67 & 0.61 & 2.99 \\
\hline
\end{tabular}

\section{DISCUSSION}

The present study describes seasonal dynamics within the benthic foraminiferal assemblage of a shallow coastal lagoon that is heavily impacted by seasonal freshwater influx from tropical monsoons. The benthic foraminiferal assemblage was studied for a period of $12 \mathrm{mo}$, with samplings carried out from 6 stations across the lagoon with an average gap of $30 \mathrm{~d}$ between each sampling. The study design provides a view of the seasonal dynamics in an environment in which tides are absent. Previous studies investigating seasonal dynamics over a much larger span

To test the impact of seasonally influenced environmental parameters in shaping the foraminiferal assemblage structure, Pearson's correlation analysis was performed with the data representing the 2 depth fractions (Table 2). In the surface $0-2 \mathrm{~cm}$ fraction, total foraminiferal abundance displayed significant positive correlation $(\mathrm{p} \leq 0.05)$ with only one factor, dissolved $\mathrm{NO}_{3}{ }^{-}$concentrations, while $H^{\prime}$ displayed none. Abundance of Ammonia T2, the highest contributor to seasonal dissimilarity, also showed a significant positive correlation with dissolved $\mathrm{NO}_{3}{ }^{-}$concentrations, while its relative abundance did not correlate with measured environmental parameters. Another member of the same genus, Ammonia T10, displayed a significant correlation between its relative abundance and salinity along with DO concentrations. Miliammina obliqua, another species that contributed to observed seasonal dissimilarities, displayed a significant positive correlation with the concentration of dissolved $\mathrm{NH}_{4}^{+}$, a relationship that was also found in the sub-surface $(2-4 \mathrm{~cm})$ fraction. In the 2-4 cm fraction, concentrations of dissolved $\mathrm{SiO}_{4}{ }^{2-}$ displayed significant negative and positive correlations with Ammomarginulina sp. and Ammonia T2 and T10, respectively. Ammomarginulina sp., which mostly characterized the $2-4 \mathrm{~cm}$ fraction during premonsoon, also displayed a significant positive correlation with salinity.
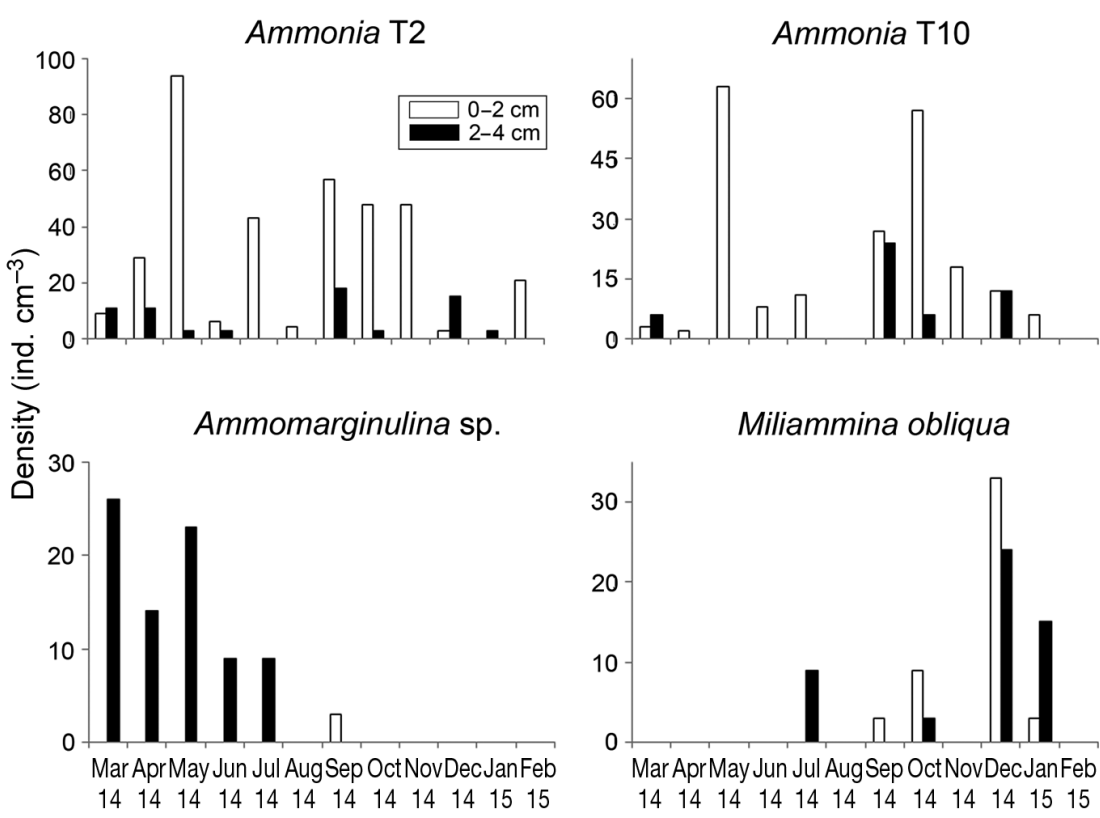

Miliammina obliqua

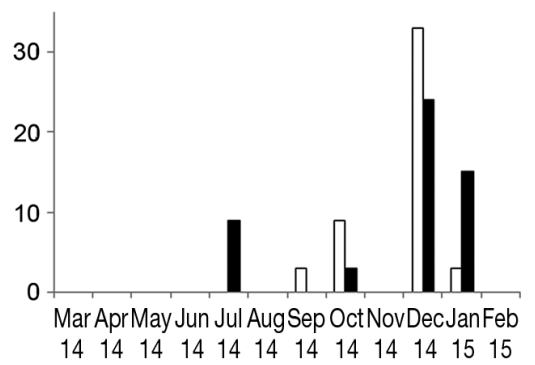

Fig. 7. Variations in the standing crop of Ammonia T2, Ammonia T10, Ammomarginulina sp. and Miliammina obliqua across the depth profile for the entire duration of the study 


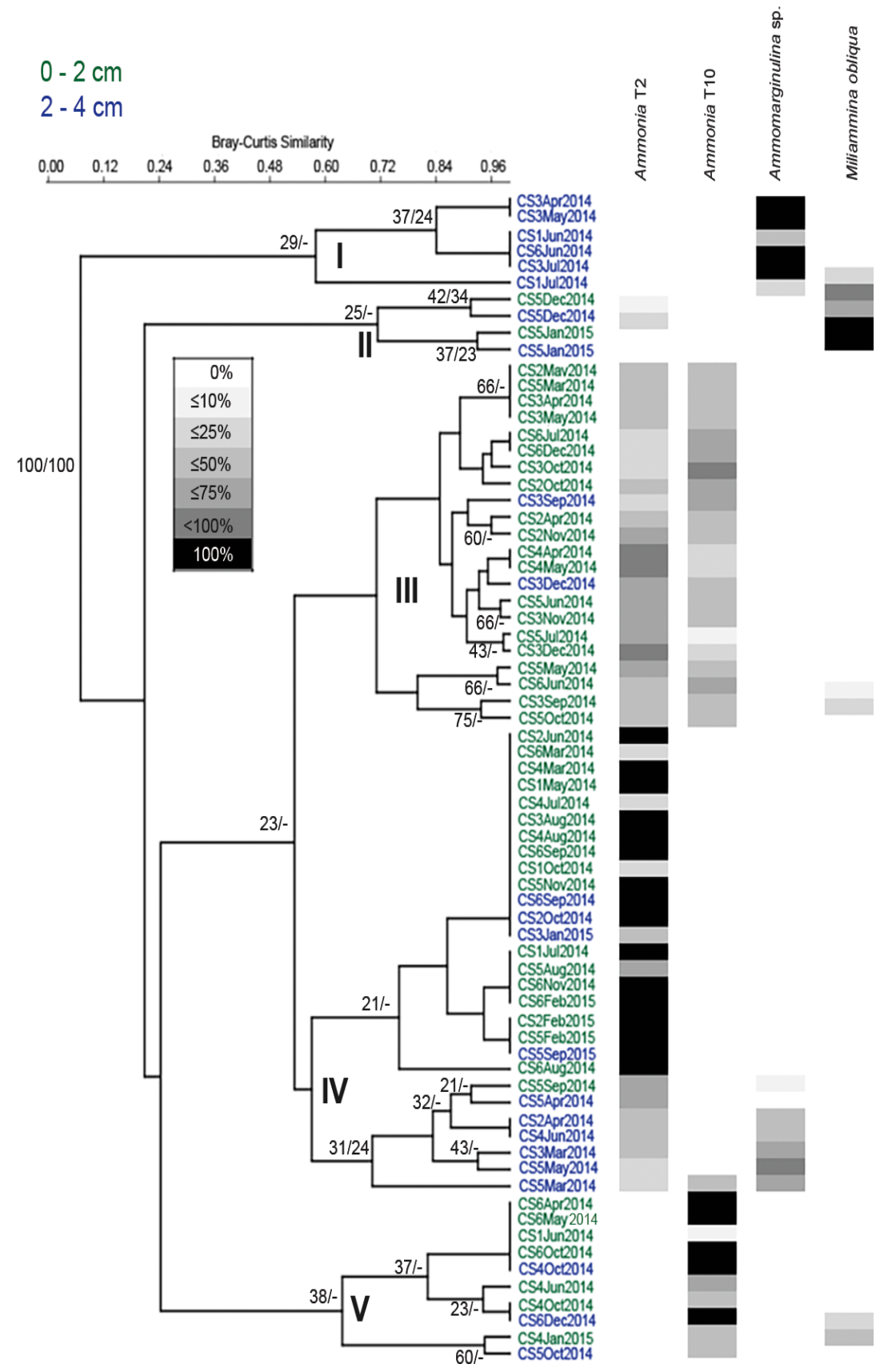

Fig. 8. UPGMA cluster analysis between collected samples with respect to the foraminiferal species that contributed most to observed seasonal differences based on Bray-Curtis similarity scale. Reliability of the clusters was tested using Bray-Curtis and Raup-Crick similarity measures, and $\geq 20 \%$ in the format of Bray-Curtis value/Raup-Crick value are shown. The shaded boxes indicate relative abundance of respective foraminiferal species from each sample

the sediment. In the present study, we did not encounter any live specimens beyond $4 \mathrm{~cm}$, with the majority of the density restricted to the surface $0-2 \mathrm{~cm}$ fractions in most of the samples.

The studied environment of Chilika lagoon has previously been reported to be under seasonal in- fluence due to the southwestern monsoon-induced precipitation and freshwater influx from the Mahanadi basin (Panigrahi et al. 2009, Srichandran et al. 2015a). During the study period, the maximum precipitation was observed during the months of July-October, which corresponds to the monsoon season in the region. Increased freshwater influx was reflected in the overall water quality. Salinity during pre-monsoon months showed greater variability among the different stations. The observed variability may stem from localized inputs of freshwater at the stations with riverine inputs. CS1 is located in the southern part of the lagoon, and, along with CS4, is remotely placed with respect to freshwater sources and closer to the marine connections of the lagoon (Table 1).

Higher variability among stations is also noted in the case of dissolved nitrate $\left(\mathrm{NO}_{3}{ }^{-}\right)$concentrations during the pre-monsoon period. Considering that the inflow of $\mathrm{NO}_{3}{ }^{-}$under coastal conditions originates from terrestrial sources, the presence of localized inputs may also explain the observed variability. Though dissolved $\mathrm{NO}_{3}{ }^{-}$levels throughout the year in the lagoon did not show any significant variation, there was a significant correlation with the number of living specimens observed.

Salinity, however, displayed the expected seasonal variation, reaching zero values during the peak of the monsoon months and increasing with the decline of precipitation in the postmonsoon period.

The $\mathrm{pH}$ at the sediment-water interface also decreased with the progression of monsoon in the region and increased with its withdrawal, reflecting the probable influence of freshwater flow into the system, which lowers the buffering capacity of seawater.

DO concentrations showed a continuous increase with study period, which may be independent of rainfall and more dependent on the wind circulation pattern in the lagoon (Mohanty \& Panda 2009); however, during monsoon, the variability between stations was lower. 
This overall impact of the monsoonal precipitation is most reflected in the concentrations of silicate $\left(\mathrm{SiO}_{4}{ }^{2-}\right)$, whereas phosphate and ammonium values did not exhibit seasonal variation. The fact that $\mathrm{SiO}_{4}{ }^{2-}$ mirrored the monsoonal precipitation shows that the majority of the $\mathrm{SiO}_{4}{ }^{2-}$ influx comes from terrestrial sources. Recent studies of the Chilika lagoon showed seasonal fluctuations in water quality; biotic communities also exhibited patterns similar to those reflected by the present study (Muduli et al. 2013, Srichandan et al. 2015a).

Stained benthic foraminiferal specimens recorded from the lagoon showed extremely low diversity and low abundance when compared with previous reports (Debenay et al. 2001, Frontalini et al. 2011) from similar settings. Previously, Kumar et al. (2015), studying live assemblages from the marine-influenced outer channel of Chilika, had reported a larger standing crop of foraminifera; however, the present study, which spans across 12 mo and was carried out mostly from the interior lagoon, reports an extremely low abundance. It must be noted that the growth of vegetation cover coupled with seasonally controlled hydrodynamics and intensified freshwater influx can bias the foraminiferal composition, increasing the amounts of allochthonous (dead) epiphytic specimens and/or totally eliminating living forms (Dimiza et al. 2016b). The correlation observed between dissolved $\mathrm{NO}_{3}{ }^{-}$and abundance on the sediment surface may originate from the aforementioned factor, as addition of nutrients to the system may assist the growth of vegetation that characterizes the shallow lagoon (Table 2). Monthly total abundances of benthic foraminifera in the lagoon ranged from 0 to 180 individuals in the surface $0-2 \mathrm{~cm}$ fraction to 0 to 57 individuals in the $2-4 \mathrm{~cm}$ vertical fraction. As $77 \%$ of total live specimens are restricted to the surface 0-2 cm fraction, it is clear that the majority of foraminiferal production is restricted to the surface sediments of the lagoon. The foraminiferal assemblage was also found to be significantly different between both depth fractions when applying ANOSIM analysis. The observed low diversity, coupled with the dominance of the stress-tolerant Ammonia, may indicate the stressed nature of the lagoon at certain times of the year.

The lagoon receives a huge load of dissolved nutrients and it is under constant threat of eutrophication (Panigrahi et al. 2009). The increased nutrient load, along with lowered values of DO during pre-monsoon versus monsoon seasons, may play a key role in shaping the biotic communities, including benthic foraminifera. According to the TROX (trophic oxy- gen) model as proposed by Jorissen et al. (1995), benthic foraminifera are restricted to the surface sediments due to the limiting nature of oxygen in deeper sediments under nutrient-rich conditions. Subsequently, values of $H^{\prime}$, along with species richness and evenness, were also higher at the surface fraction in comparison to the $2-4 \mathrm{~cm}$ fraction. Amongst the 12 species of benthic foraminifera recorded in the present study, Trochammina inflata and Quinqueloculina seminulum were only recorded from the surface fraction. Agglutinated species such as Ammotium salsum, Textularia agglutinans and Miliammina fusca are known to dominate nearshore vegetated environments (Murray \& Alve 2000, Horton et al. 2003, 2005), along with T. inflata and Q. seminulum. The porcelaneous species $Q$. seminulum is known to characterize low vegetated zones and is also common in the shallow marine waters of the Mediterranean (Jorissen 1988, Sgarrella \& Moncharmont Zei 1993, Murray 2006, Dimiza et al. 2016a,b).

SIMPER analysis performed to determine the contribution of each species to differences that might exist in the benthic assemblage structure revealed Ammonia T2 and Ammonia T10 to be the major contributors of observed differences in assemblage structure across seasons. This analysis was performed by indexing the samples by season irrespective of depth, which further stresses the dominance of members of the genus Ammonia in the benthic foraminiferal assemblage of the lagoon. Amongst the other species, Ammomarginulina sp. and Miliammina obliqua contributed more than $10 \%$ to dissimilarities observed between seasons. UPGMA cluster analysis based on Bray-Curtis similarity between collected samples across seasons and depth profile better represents the seasonal variations within the assemblage studied. Observed clusters reflected the presence and absence of seasonality among the benthic foraminiferal species used for analysis. As mentioned in the 'Results', Cluster I comprised mostly samples collected during the post-monsoon and was characterized by a dominance of $M$. obliqua (Fig. 8). Others members of the genus Miliammina are known to be epiphytes and their observed dominance during the post-monsoon may be correlated with the increased values of DO during that time period. But no such correlation was identified in the present study. However, M. obliqua displayed a significant positive correlation with dissolved $\mathrm{NH}_{4}{ }^{+}$concentration. This observation, coupled with the fact that higher abundance of the species was restricted to a certain station in a certain period of time, may indicate the existence of yet-to-be-identified factors 
required by the species. High values of DO may be an indicator of higher primary productivity in the lagoon from surface water phytoplankton and submerged macrophytes (Srichandan et al. 2015b), with the latter possibly acting as a substrate for $M$. obliqua. In the cluster analysis, pre-monsoon and postmonsoon samples with a dominance of Ammonia T10 formed a separate group (Cluster III), while another group (Cluster IV) was mainly composed of monsoon samples with an almost absolute dominance of Ammonia species. The dominance of the genus may be an indicator of the stressed nature of the lagoon, as Ammonia is known to be a stress-tolerant genus exhibiting a ubiquitous distribution across nearshore environments (Hayward et al. 2004, Dimiza et al. 2016a,b). Al-Zamel \& Cherif (1998), in a study of the live sub-tidal assemblage from the Shatt Al-Arab delta, Kuwait, identified Ammonia T2 syn. aberdoveyensis as inhabiting brackish creek environments with lowered abundance in open marine regions. Another observed species, Ammonia T6 syn. aomoriensis, has been also known to characterize brackish water environments (Haynert et al. 2011, Haynert \& Schönfeld 2014). In particular, the closely related Ammonia tepida is commonly reported as opportunistic, tolerant to lower salinities and/or salinity fluctuations in shallow marine, lagoonal and deltaic environments (AlmogiLabin et al. 1992, Yanko et al. 1998; Debenay et al. 2005, Frontalini et al. 2009, Koukousioura et al. 2012, Martins et al. 2013, Dimiza et al. 2016a,b).

Observed low values in DO during the premonsoon, coupled with increased nutrient loading during monsoon, may act as inducers of stress in this shallow coastal lagoon. Previous studies from Chilika have reported the occurrence of phytoplankton blooms during pre-monsoon, highlighting the threat of eutrophication faced by the lagoon (Panigrahi et al. 2009). The dominance of Ammonia in the live assemblage throughout the study and across the studied sediment depth also supports the potential threats from eutrophication, as Ammonia T2 displayed a significant positive correlation with dissolved $\mathrm{NO}_{3}{ }^{-}$. The dominance of members from a single genus is also reflected in Simpson's evenness values, which were mostly low $(<0.5)$ during the study period. Similar dominance of Ammonia in the living assemblage has been previously reported from Venice lagoon, Italy (Donnici et al. 1997), and from Ria de Aveiro lagoon, Portugal (Martins et al. 2013), both of which are highly influenced by tidal influx. However, similar dominance has also been reported from Araruama lagoon, Brazil (Debenay et al. 2001), Lake Varano lagoon, Italy (Frontalini et al. 2011), and
Aegean coastal lagoons (Koukousioura et al. 2012, Dimiza et al. 2016a,b), which have limited tidal influence, similar to the present study. The dominance of Ammonia therefore appears to be independent of tidal regime. Debenay et al. (2001) relate this dominance to the seasonal lowering of salinity coupled with increased nutrient loading, while Martins et al. (2013) and Dimiza et al. (2016b) postulate that the dominance of Ammonia is also due to their greater tolerance of pollutants under coastal settings. Seasonal variation in the living assemblage was most pronounced in the case of Ammomarginulina sp.: along with their restricted occurrence in the sub-surface $2-4 \mathrm{~cm}$ fraction, they formed an entirely separate cluster (Cluster I). Limited occurrence of this species in the live assemblage during pre-monsoon (Fig. 8) may reflect its stress-sensitive nature and during this period lowest DO concentrations, along with increased salinity, also showed significant positive correlation with the above species across both depths. However, such depth-specific microhabitats are not known to exist globally (Murray 2006).

Other than the temporal and vertical distributional dynamics, living benthic foraminiferal assemblages are known to exhibit patchiness laterally. Murray \& Alve (2000) reported a difference in benthic foraminiferal assemblages separated by a few centimeters. Vertical distribution of foraminifera in marginal habitats has often being linked with the presence and absence of bioturbating agents (Saffert \& Thomas 1998, Alve \& Murray 2001). Alve \& Murray (2001) studied the intertidal foraminiferal assemblage at Hamble Estuary, UK, and concluded that the observed restriction of the majority of the assemblage to the upper $1 \mathrm{~cm}$ was due to absence of bioturbation. Presence of overlying vegetation can also play a major role in determining the depth of the foraminiferal assemblage. Duchemin et al. (2005), studying the marsh foraminiferal assemblage from the Gulf of Morbihan, France, found a greater number of living specimens up to a depth of $9 \mathrm{~cm}$ in vegetated zones as compared with unvegetated areas. In the present study area, the presence of bioturbating agents such as macrofauna in the sediment, along with the presence of rooted macrophytes, has been linked with seasonal variations in water quality (Mahapatro et al. 2009, Jaikumar et al. 2011). In the present study, Ammomarginulina sp., which dominated the subsurface assemblage in the pre-monsoon months, displayed significant correlation with dissolved $\mathrm{SiO}_{4}^{-}$, a nutrient that is known to support phytal production in the lagoon (Panigrahi et al. 2009). 
The present study also recorded significant differences on the horizontal plane with respect to study sites based on ANOSIM analysis. The presence of spatial variation among the living assemblage complicates interpretations of hypotheses investigating temporal and horizontal changes. The different sources of influx, as outlined in Table 1, also had effects on the conditions prevailing at the time of collection, as well as the underlying assemblage structure. However, the variation in foraminiferal assemblage due to spatial patchiness was close to being uniform throughout the study period and did not result in any separate clustering of samples in the cluster analysis. The impact of seasonally varying environmental factors on shaping the assemblage was not pronounced, as seen from the correlation analysis. While certain environmental parameters were correlated with certain species, no single parameter could be identified as the major driving force shaping the overall assemblage in the lagoon. Seasonal influx of certain dissolved nutrients $\left(\mathrm{NO}_{3}{ }^{-}\right.$, $\mathrm{SiO}_{4}^{-}, \mathrm{NH}_{4}{ }^{+}$) may influence the productivity of the lagoon, which in turn may shape the structure of bottom-dwelling foraminifera. Environmental monitoring utilizing foraminiferal proxies in nearshore environments are known to provide an economic tool for environmental assessment (Hallock 2012). Recently, Dimiza et al. (2016b) have introduced the Foram Stress Index for classifying soft-bottom environments, where high input of nutrients coupled with anthropogenic stressors can lead to the development of assemblages dominated by stress-tolerant taxa such as Ammonia and Textularia agglutinans. The low diversity observed in the present study can thus be interpreted to stem from seasonal nutrient loading in the system. Correlations observed between nutrients and stress-tolerant taxa such as Ammonia can thus further improve environmental monitoring using foraminiferal proxies.

\section{CONCLUSIONS}

The objectives of the present study were to characterize the live assemblage from a tropical monsooninfluenced coastal lagoon in Chilika, India, and study the seasonal variation observed across the vertical sediment profile from this shallow water body over a period of $1 \mathrm{yr}$. The study revealed the live assemblage to be composed of a low-diversity benthic foraminiferal population mostly dominated by members of the genus Ammonia. The species observed mostly were agglutinated in nature, apart from Ammonia spp. and Quinqueloculina seminulum. The live assemblage was found to be restricted to the upper $4 \mathrm{~cm}$ of the sediment, with the majority of foraminifera occurring in the surface $2 \mathrm{~cm}$ fraction. ANOSIM analysis revealed the existence of significant differences in the assemblage composition between the depth profiles studied, and also among the stations. Cluster analysis of collected samples reflected seasonal variations in the assemblage with respect to agglutinated species of Ammomarginulina sp. and Miliammina obliqua, but the dominant calcareous specimens of Ammonia spp. did not exhibit temporal variation. Incorporation of seasonal variations in such proxies may generate wider application and better understanding of present estimates with respect to tropical and sub-tropical marginal marine environments. Overall, the benthic foraminifer dataset generated as part of this study could be used not only for long-term ecological monitoring of Chilika lagoon, but also to investigate biogeographic patterns of foraminifer communities in other coastal ecosystems.

Acknowledgements. The authors thank Kashinath Sahu, IISER Kolkata, for assistance during FESEM imaging. A.S. thanks IISER Kolkata for providing a PhD fellowship. P.B. acknowledges IISER Kolkata for providing grants to undertake this study. The authors also acknowledge the 3 anonymous reviewers, whose scientific input has helped immensely in improving the manuscript.

\section{LITERATURE CITED}

Al-zamel AZ, Cherif $\mathrm{OH}$ (1998) Subtidal foraminiferal assemblages of the western part of the Shatt Al-Arab Delta, Kuwait, Arabian Gulf. J Foraminiferal Res 28:327344

Almogi-Labin A, Perelis-Grossovicz L, Raab M (1992) Living Ammonia from a hypersaline inland pool, Dead Sea area, Israel. J Foraminiferal Res 22:257-266

Alve E (1995) Benthic foraminiferal responses to estuarine pollution: a review. J Foraminiferal Res 25:190-203

Alve E, Murray JW (2001) Temporal variability in vertical distributions of live (stained) intertidal foraminifera, southern England. J Foraminiferal Res 31:12-24

Anthony A, Atwood J, August PV, Byron C and others (2009) Coastal lagoons and climate change: ecological and social ramifications in U.S. Atlantic and Gulf Coast ecosystems. Ecol Soc 14:8

Bernhard JM (2000) Distinguishing live from dead foraminifera: methods review and proper applications. Micropaleontol 46:38-46

Bhattacharjee D, Choudhury BC, Sivakumar K, Sharma C and others (2013) Benthic foraminifer assemblages in turtle congregation sites along the North East coast of India. J Mar Biol Assoc UK 93:877-887

Buzas MA, Hayek LC (2000) A case for long-term monitoring of the Indian River Lagoon, Florida: foraminiferal densities, 1977-1996. Bull Mar Sci 67:805-814 
Buzas MA, Hayek LC, Reed SA, Jett JA (2002) Foraminiferal densities over five years in the Indian River Lagoon, Florida: a model of pulsating patches. J Foraminiferal Res 32:68-92

> Choudhury AK, Das M, Philip P, Bhadury P (2015) An assessment of the implications of seasonal precipitation and anthropogenic influences on a mangrove ecosystem using phytoplankton as proxies. Estuaries Coasts 38: 854-872

> Debenay JP, Tsakridis E, Southard R, Grossel H (2001) Factors determining the distribution of foraminiferal assemblages in Port Joinville Harbor (Ile d'Yeu, France): the influence of pollution. J Mar Micropaleontol 43:75-118

> Debenay JP, Millet B, Angelidis MO (2005) Relationships between foraminiferal assemblages and hydrodynamics in the gulf of Kalloni, Greece. J Foraminiferal Res 35: 327-343

> Defeo O, McLachlan A, Schoeman DS, Schlacher TA and others (2009) Threats to sandy beach ecosystems: a review. Estuar Coast Shelf Sci 81:1-12

> Devi GS, Rajashekhar KP (2009) Intertidal foraminifera of Indian coast-a scanning electron photomicrograph illustrated catalogue. J Threatened Taxa 1:17-36

> Dimiza MD, Koukousioura O, Triantaphyllou MV, Dermitzakis MD (2016a) Benthic foraminiferal assemblages from coastal environments of the Aegean Sea (Greece). Rev Micropaleontol 59:19-32

> Dimiza MD, Triantaphyllou MV, Koukousioura O, Hallock P, Simboura N, Karageorgis AP, Papathanasiou E (2016b) The Foram Stress Index: a new tool for environmental assessment of soft-bottom environments using benthic Foraminifera. A case study from the Saronikos Gulf, Greece, Eastern Mediterranean. Ecol Indic 60:611-621

> Donnici S, Barbero RS, Taroni G (1997) Live benthic foraminifera in the lagoon of Venice (Italy): population dynamics and its significance. Micropalaeontol 43:440-454

> Duchemin G, Jorissen FJ, Redois F, Debenay JP (2005) Foraminiferal microhabitats in a high marsh: Consequences for reconstructing past sea levels. Palaeogeogr Palaeoclimatol Palaeoecol 226:167-185

> Finch MS, Hydes DJ, Clayson CH, Weigl B, Dakin J, Gwilliam P (1998) A low power ultra violet spectrophotometer for measurement of nitrate in seawater: introduction, calibration and initial sea trials. Anal Chim Acta 377:167-177

> Frontalini F, Buosi C, Da Pelo S, Coccioni R, Cherchi A, Bucci C (2009) Benthic foraminifera as bio-indicators of trace element pollution in the heavily contaminated Santa Gilla lagoon (Cagliari, Italy). Mar Pollut Bull 58: 858-877

Frontalini F, Margaritelli G, Francescangeli F, Rettori R, Armynot Du Châtelet E, Coccioni R (2011) Benthic foraminiferal assemblages and biotopes in a coastal lake: the case study of Lake Varano (southern Italy). Acta Protozool 52:147-160

- Gehrels WR, Newman SWG (2004) Salt-marsh foraminifera in Ho Bugt, western Denmark, and their use as sea-level indicators. Dan J Geogr 104:97-106

Gilman EL, Ellison J, Duke NC, Field C (2008) Threats to mangroves from climate change and adaptation options: a review. Aquat Bot 89:237-250

Goldstein ST, Watkins GT, Kuhn RM (1995) Microhabitats of salt marsh foraminifera: St. Catherines Island, Georgia, USA. Mar Micropaleontol 26:17-29

Gupta GVM, Sarma VVSS, Robin RS, Raman AV, Jai Kumar
M, Rakesh M, Subramanian BR (2008) Influence of net ecosystem metabolism in transferring riverine organic carbon to atmospheric $\mathrm{CO}_{2}$ in a tropical coastal lagoon (Chilika Lake, India). Biogeochem 87:265-285

Hallock P (2012) The FoRAM Index revisited: uses, challenges, and limitations, Proceedings of the 12th International Coral Reef Symposium, Cairns, Australia, p 9-13

Hammer $\varnothing$, Harper DAT, Ryan PD (2001) PAST: paleontological statistics software package for Education and data analysis. Palaeontol Electronica 4:1-9

Haynert K, Schönfeld J (2014) Impact of changing carbonate chemistry, temperature, and salinity on growth and test degradation of the benthic foraminifer Ammonia aomoriensis. J Foraminiferal Res 44:76-89

> Haynert K, Schönfeld J, Riebesell U, Polovodova I (2011) Biometry and dissolution features of the benthic foraminiferal species Ammonia aomoriensis at high $\mathrm{pCO}_{2}$. Mar Ecol Prog Ser 432:53-67

Hayward BW, Holzmann M, Grenfell HR, Pawlowski J, Triggs CM (2004) Morphological distinction of molecular types in Ammonia towards a taxonomic revision of the world's most commonly misidentied foraminifera. Mar Micropaleontol 50:237-271

Horton BP, Murray JW (2007) The roles of elevation and salinity as primary controls on living foraminiferal distributions: Cowpen Marsh, Tees estuary, UK. Mar Micropaleontol 63:169-186

Horton BP, Larcombe $\mathrm{P}$, Woodrofee SA, Whittaker JE, Wright MR, Wynn C (2003) Contemporary foraminiferal distributions of a mangrove environment, Great Barrier Reef coastline, Australia: implications for sea-level reconstructions. Mar Geol 198:225-243

> Horton BP, Whittaker JE, Thompson KH, Hardbattle MIJ, Kemp A, Woodrofee SA, Wright MR (2005) The development of a modern foraminiferal data set for sea-level reconstructions, Wakatobi Marine National Park, Southeast Sulawesi, Indonesia. J Foraminiferal Res 35:1-14

Jaikumar M, Chellaiyan D, Kanagu L, Kumar PS, Stella C (2011) Distribution and succession of aquatic macrophytes in Chilka Lake, India. J Ecol Nat Environ 3: 499-508

Jayalakshmy KV, Rao KK (2001) Frequency distribution of Foraminifera in the Chilka Lake. J Mar Biol Assoc India 43:65-80

> Jeong KS, Kim DK, Pattnaik A, Bhatta K, Bhandari B, Joo GJ (2008) Patterning limnological characteristics of the Chilika lagoon (India) using a self-organizing map. Limnology 9:231-242

Jorissen FJ (1988) Benthic foraminifera from the Adriatic Sea: principles of phenotypic variation. Utrecht Micropaleontological Bulletins 37:531-538

Jorissen FJ, de Stigter HC, Widmark JGV (1995) A conceptual model explaining benthic foraminiferal microhabitats. Mar Micropaleontol 26:3-15

- Kennish MJ (2002) Environmental threats and environmental future of estuaries. Environ Conserv 29:78-107

Koukousioura O, Triantaphyllou MV, Dimiza MD, Pavlopoulos K, Syrides G, Vouvalidis K (2012) Benthic foraminiferal evidence and paleoenvironmental evolution of Holocene coastal plains in the Aegean Sea (Greece). Quat Int 261:105-117

Kumar RA, Naidu KB, Kaladhar R (2015) Agglutinated foraminifera from the Chilika Lake, Orissa, east coast of India. Ind J Geo-Mar Sci 44:531-538

Liddicoat MI, Tibbits S, Buttler AI (1975) The determination 
of ammonia in seawater. Limnology 20:131-132

Loeblich AR, Tappan H (1987) Foraminiferal genera and their classification. Van Nostrand Reinhold Company, New York

Luan BT, Debenay JP (2005) Foraminifera, environmental bioindicators in the highly impacted environments of Mekong Delta. Hydrobiologia 548:75-83

Mahapatro D, Panigrahy RC, Panda S, Mishra RK (2009) Influence of monsoon on macrobenthic assemblage in outer channel area of Chilika lagoon, east coast of India. J Wetland Ecol 3:56-67

Martins VA, Frontalini F, Tramonte KM, Figueira RCL and others (2013) Assessment of the health quality of Ria de Aveiro (Portugal): heavy metals and benthic foraminifera. Mar Pollut Bull 70:18-33

Maybury CA, Gwynn IAP (1993) Wet processing of recent calcareous foraminifera: methods for preventing dissolution. J Micropalaeontol 12:67-69

McGlathery KJ, Anderson IC, Tyler AC (2001) Magnitude and variability of benthic and pelagic metabolism in a temperate coastal lagoon. Mar Ecol Prog Ser 216:1-15

McGlathery KJ, Sundbäck K, Anderson IC (2007) Eutrophication in shallow coastal bays and lagoons: the role of plants in the coastal filter. Mar Ecol Prog Ser 348:1-18

Mohanty PK, Panda BUS (2009) Circulation and mixing processes in Chilika lagoon. Ind J Geo-Mar Sci 38:205-214

Muduli PR, Kanuri VV, Robin RS, Charan Kumar B and others (2012) Spatio-temporal variation of CO2 emission from Chilika Lake, a tropical coastal lagoon, on the east coast of India. Estuar Coast Shelf Sci 113:305-313

Muduli PR, Kanuri VV, Robin RS, Charan Kumar B and others (2013) Distribution of dissolved inorganic carbon and net ecosystem production in a tropical brackish water lagoon, India. Cont Shelf Res 64:75-87

Murray JW (2006) Ecology and applications of benthic foraminifera. Cambridge University Press, Cambridge

Murray JW, Alve E (2000) Major aspects of foraminiferal variability (standing crop and biomass) on a monthly scale in an intertidal zone. J Foraminiferal Res 30:177-191

Naik S, Panigrahy RC, Mohapatra A (2008) Spatio-temporal distribution of zooplankton in Chilka lake-a Ramsar site on the Indian east coast. Ind J Sci Tech 1:1-5

Nayak L, Behera DP (2004) seasonal variation of some physico-chemical parameters of Chilika lagoon (east coast of India) after opening the new mouth near Sipakuda. Ind J Geo-Mar Sci 33:206-208

Panda US, Mohanty PK (2008) Monitoring and modeling of Chilika environment using remote sensing data. Proc TAAL 2007:617-638

Editorial responsibility: Roderick Finn, Bergen, Norway
Panigrahi S, Wikner J, Panigrahy RC, Satapathy KK, Acharya BC (2009) Variability of nutrients and phytoplankton biomass in a shallow brackish water ecosystem (Chilika lagoon, India). Limnology 10:73-85

> Papaspyrou S, Diz P, García-Robelo E, Corzo A, JimenezAriaz JL (2013) Benthic foraminiferal community changes and their relationship to environmental dynamics in intertidal muddy sediments (Bay of Cádiz, SW Spain). Mar Ecol Prog Ser 490:121-135

$>$ Rodrigues AR, Braga ES, Eichler BB (2015) Living foraminifera in the shallow waters of Admiralty bay: distributions and environmental factors. J Foraminiferal Res 45:128-145

Saffert H, Thomas E (1998) Living foraminifera and total populations in salt marsh peat cores: Kelsey Marsh (Clinton, CT) and the Great Marshes (Barnstable, MA). Mar Micropaleontol 33:175-202

Sahu BK, Pati P, Panigrahy RC (2014) Environmental condition off Chilika lake during pre and post hydrological intervention: an overview. J Coast Conserv 18:285-297

Samir AM (2000) The response of benthic foraminifera and ostracods to various pollution sources: a study from two lagoons in Egypt. J Foraminiferal Res 30:83-98

Schönfeld J, Alve E, Geslin E, Jorissen F, Korsun S, Spezzaferri S (2012) The FOBIMO (FOraminiferal BIo-MOnitoring) initiative-towards a standardised protocol for softbottom benthic foraminiferal monitoring studies. Mar Micropaleontol 94-95:1-13

Sgarrella F, Moncharmont Zei M (1993) Benthic foraminifera of the Gulf of Naples (Italy): systematics and autoecology. Boll Soc Paleontol Ital 32:145-264

Srichandan S, Kim JY, Bhadury P, Barik SK and others (2015a) Spatiotemporal distribution and composition of phytoplankton assemblages in a coastal tropical lagoon: Chilika, India. Environ Monit Assess 187:47

Srichandan S, Kim JY, Kumar A, Mishra DR and others (2015b) Interannual and cyclone-driven variability in phytoplankton communities of a tropical coastal lagoon. Mar Pollut Bull 101:39-52

Strickland JDH, Parsons TR (1972) A practical handbook of seawater analysis. Fisheries Research Board of Canada, Ottawa

> Turner RE, Qureshi N, Rabalais NN, Dortch Q, Justic D, Shaw RF, Cope J (1998) Fluctuating silicate: nitrate ratios and coastal plankton food webs. Proc Natl Acad Sci USA 95:13048-13051

Yanko V, Ahmad M, Kaminski MA (1998) Morphological deformities of benthic foraminiferal tests in response to pollution by heavy metals: implications for pollution monitoring. J Foraminiferal Res 28:177-200

Submitted: February 11, 2016; Accepted: June 20, 2016

Proofs received from author(s): September 7, 2016 